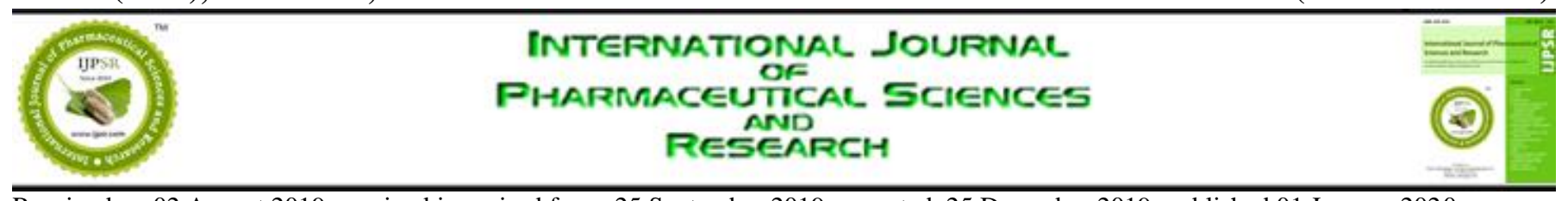

Received on 02 August 2019; received in revised form, 25 September 2019; accepted, 25 December 2019; published 01 January 2020

\title{
SYNTHESIS AND ANTICONVULSANT ACTIVITY OF SOME NOVEL BENZOTRIAZOLE DERIVATIVES
}

\author{
V. K. Singh ${ }^{*}$, , Poonam Rishishwar ${ }^{2}$, Peeyush Bharadwaj ${ }^{3}$ and Shashi Alok ${ }^{3}$
}

School of Pharmacy ${ }^{1}$, Monad University, Panchsheel Nagar, Hapur - 245304, Uttar Pradesh, India. Arunachal University of Studies ${ }^{2}$, Namsai - 792103, Arunachal Pradesh, India.

Institute of Pharmacy ${ }^{3}$, Bundelkhand University, Jhansi - 284127, Uttar Pradesh, India.

Keywords:

Benzotriazole, Thiadiazole, Thiazolidinone, Anticonvulsant activity, Seizures, Maximal electroshock (MES),

Hind limb tonic extension (HLTE), Grand mal epilepsy

Correspondence to Author: V. K. Singh

Research Scholar (Ph.D.), School of Pharmacy, Monad University, Panchsheel Nagar, Hapur - 245304, Uttar Pradesh, India.

E-mail: vijayquantum@gmail.com

\begin{abstract}
The vast investigations on the derivatives of 1, 2, 3benzotriazole explore wide applicability for tagging and delivering a number of other heterocyclic nuclei with benzotriazole. In the present work, several derivatives of 1-(substituted)-5- [(N-benzotriazolomethyl)-1, 3, 4-thiadiazolyl]- imidazole-2-thione have been synthesized and are evaluated for their anticonvulsant activity. The anticonvulsant activities of the synthesized derivatives were assessed by the maximal electroshock (MES) method. Electric shock $(50 \mathrm{~mA}$ for $0.2 \mathrm{sec}$ ) was delivered with the help of a corneal electrode to induce hind limb tonic extension. The synthesized derivatives X2, X3 and X6 exhibited significant anticonvulsant effect against MESinduced seizure model as an indication for compounds which are effective in grand mal epilepsy.
\end{abstract}

INTRODUCTION: 1, 2, 3-benzotriazoles were reported to have potential fungicidal ${ }^{1}$ and antibacterial activity ${ }^{2}$. Similarly, 1, 3, 4-thiadiazole derivatives were also reported to possess fungicidal, herbicidal, bactericidal ${ }^{3}$, pesticidal, insecticidal, antihistaminic, anti-amoebic ${ }^{4}$, CNS depressant, antihypertensive, anticonvulsant, hypnotic, analgesic ${ }^{5}$, anti-inflammatory ${ }^{6}$ and agonist for 5-Ht receptor ${ }^{7}$. 4-thiazolidinone nucleus has also occupied a unique place in the field of medicinal chemistry due to its wide range of biological activities like antibacterial, anticancer 8

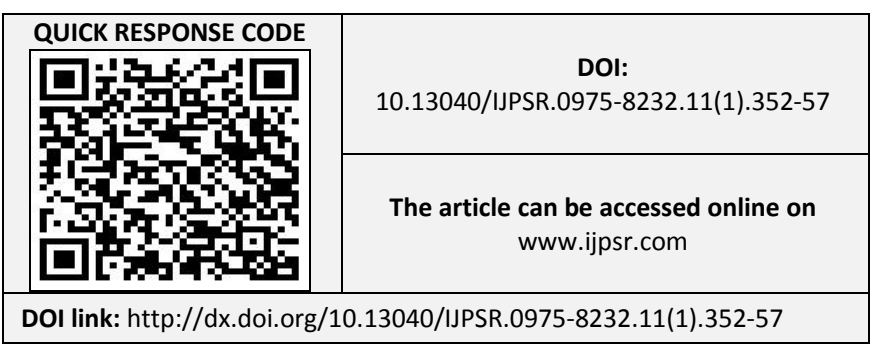

Respiratory, syncytial, virus Inhibitor 9, anticonvulsant ${ }^{10}$, sciatic nerve blocking, local anaesthetic, inhibitors of human (CK2) protein kinase ${ }^{11}$, hypnotic, fungicidal, cysticidal, antileukemic and antioxidant activity. In view of potential biological activities of benzotriazole, thiadiazole and imidazole an attempt was made to unite these nuclei together and synthesize some new derivatives of benzotriazole (X1-X6) to screen out some derivatives for significant anticonvulsant activity. The procedure of synthesis has been outlined in Scheme 1.

In India, dissemination of epilepsy was reported to be 5.5-7.9 per 1,000 persons which are around $1 / 18^{\text {th }}$ of the total population of India ${ }^{12}$. The most common anticonvulsant drugs used for the treatments of epilepsy are phenytoin, valproate, carbamazepine, phenobarbital, primidone, and lamotrigine. The currently available drugs, if used judiciously and continuously, abolish seizures 
completely in $60 \%-80 \%$ of the patients and reduce their frequency in another $10 \%-20 \%$ of the patient. Despite their effectiveness, most of them produce many side effects like drowsiness, nausea, mental dullness, ataxia, teratogenesis, hematological changes, weight gain, paresthesia, hirsutism, congenital malformations and hypertrophy of gums. For these reasons, there is a need for developments of new anticonvulsant drugs to improve epilepsy control and reduce its harmful effects ${ }^{13}$.

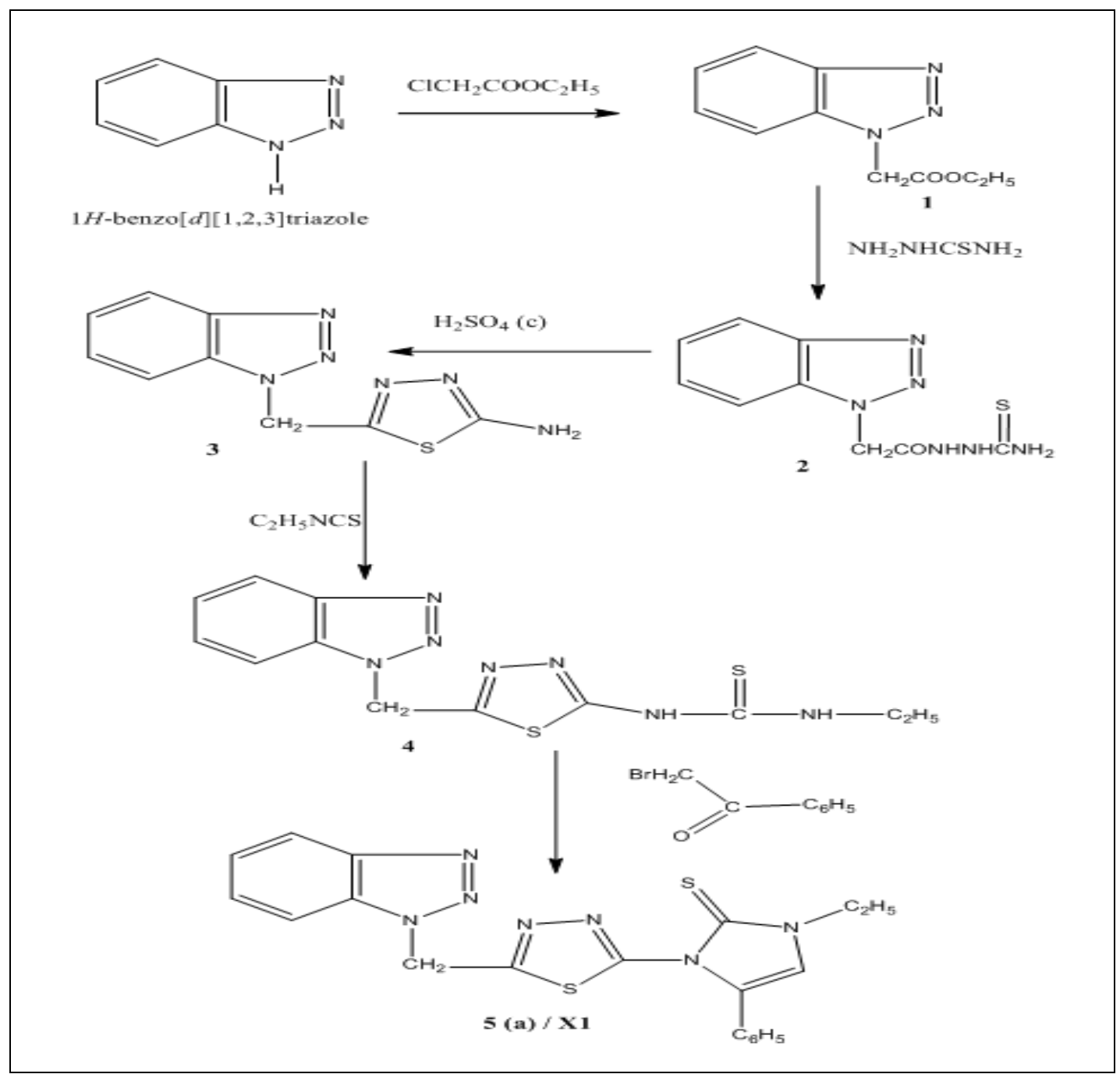

SCHEME 1: SYNTHESIS OF 1-(SUBSTITUTED)-5-[(N-BENZOTRIAZOLOMETHYL)-1, 3, 4-THIADIAZOLYL]IMIDAZOLE-2-THIONE DERIVATIVES

MATERIALS AND METHODS: The chemicals and reagents used in this were of AR and LR grade. They were procured from CDH, Hi-Media, Merck, Sigma Aldrich, and Ranbaxy and the standard drug phenytoin were procured as a gift sample from Royal Research Center, Navsari, Gujarat, The melting points of the synthesized compounds were determined by using Thiel's melting point apparatus (open capillary tube method) and all the compounds gave sharp melting points and are uncorrected. The purity of the compounds was ascertained by thin-layer chromatography using silica gel-G as stationary phase and appropriate mixtures of the following solvents as mobile phase: n-butanol, glacial acetic acid and water. The spots resolved were visualized using the iodine chamber. The IR spectra of the synthesized compounds were recorded on a Fourier Transform IR spectrophotometer (Perkin Elimer BX-II) in the range of 400-4000 using diffuse reflectance system and values of peaks $(v)$ are reported in cm-1. 1H NMR spectra were recorded on Bruker Av- II $400 \mathrm{MHz}$ NMR spectrometer and chemical shifts $(\delta)$ are reported in ppm downfield from internal reference Tetramethylsilane (TMS). Mass spectra were recorded on Shimadzu LC-MS model 2010A. 
Elemental analysis of the newly synthesized compounds was carried out using Euro - E 3000 series elemental analyzer. 1-(substituted)-5-[(Nbenzotriazolomethyl)-1, 3, 4-thiadiazolyl] imidazole-2-thione were prepared as per the method described in the literature ${ }^{14-16}$. The synthetic procedure involved the following six steps as stated below.

\section{Experimental Section:}

Ethyl N1-benzotriazoloacetate, 1: A mixture of benzotriazole ( 0.1 mole), ethyl chloroacetate $(0.1$ mole) and $\mathrm{K}_{2} \mathrm{CO}_{3}(3 \mathrm{~g})$ in acetone $(60 \mathrm{ml})$ was stirred for $8 \mathrm{~h}$. The solvent was then removed under reduced pressure and the solid mass obtained are subjected to extraction with petroleum ether. The solvent was removed under reduced pressure to yield needle shaped brown crystals of compound 1; yield $90 \%$, m.p. $39-40{ }^{\circ} \mathrm{C}$. Elemental analysis: Found C, 58.6\%; H, 5.4\%; N, 20.4\% Calc. for $\mathrm{C}_{10} \mathrm{H}_{11} \mathrm{~N}_{3} \mathrm{O}_{2}$; C, 58.5\%; H, 5.4\%; N, 20.5\%; IR: $1740(\mathrm{C}=\mathrm{O}) ; 1232,1462\left(\mathrm{~N}-\mathrm{CH}_{2}\right) ; 1 \mathrm{HNMR}\left(\mathrm{D}_{2} \mathrm{O}\right)$ : $3.75\left(\mathrm{~s}, 2 \mathrm{H}, \mathrm{N}-\mathrm{CH}_{2}\right), 4.25\left(\mathrm{q}, 2 \mathrm{H}, \mathrm{COOCH}_{2}\right), 1.30$ $\left(\mathrm{t}, 3 \mathrm{H}, \mathrm{CH}_{3}\right)$ and 6.90-7.91 (m, $\left.4 \mathrm{H}, \mathrm{ArH}\right) ; \mathrm{MS}: \mathrm{m} / \mathrm{z}$ $205(\mathrm{M}+)$.

1-(N1-benzotriazoloacetyl)-thiosemicarbazide, 2: Compound 1 (0.07 mole) and thiosemicarbazide (0.07 mole) in ethanol $(50 \mathrm{ml})$ was stirred for $5 \mathrm{~h}$ and then refluxed on steam bath for $2 \mathrm{~h}$. The excess of solvent was removed under reduced pressure and recrystallised from chloroform-hexane $(2: 1 \mathrm{v} / \mathrm{v})$ to yield pale yellow crystals of product 2; yield $86 \%$, m.p. $103-104{ }^{\circ} \mathrm{C}$. Elemental analysis: Found $\mathrm{C}$, $43.3 \% ; \mathrm{H}, 4.1 \%$; N, 33.5\% Calc. for $\mathrm{C}_{9} \mathrm{H}_{10} \mathrm{~N}_{6} \mathrm{OS}$; C, 43.2\%; H, 4.1\%; N, 33.6\%; IR: $3340\left(-\mathrm{NH}_{2}\right)$; 1670 (-CONH-); $1130(\mathrm{C}=\mathrm{S})$; $1 \mathrm{HNMR}\left(\mathrm{CDCl}_{3}\right)$ : $3.80\left(\mathrm{~s}, 2 \mathrm{H}, \mathrm{N}-\mathrm{CH}_{2}\right), 8.30(\mathrm{~m}, 4 \mathrm{H}, \mathrm{NH}-\mathrm{NH}-\mathrm{CS}-$ $\mathrm{NH}_{2}$ ), and 6.45-7.21 (m, 4H, ArH); MS: m/z 250 $\left(\mathrm{M}^{+}\right)$

2-amino-5-(N1- benzotriazolomethyl)- 1, 3, 4 thiadiazole, 3: The thiosemicarbazide $2(0.05$ mole) together with conc. $\mathrm{H}_{2} \mathrm{SO}_{4}(10 \mathrm{ml})$ was kept overnight at room temperature, neutralized with ammonia and extracted with ether. The ether was distilled off and the product so obtained was crystallised from $80 \%$ ethanol to get yellowish leaflet of compound 3; yield 85\%, m.p. $120-121^{\circ} \mathrm{C}$ (d). Elemental analysis: Found C, 46.5\%; H, 3.4\%; $\mathrm{N}, 36.0 \%$ Calc. for $\mathrm{C}_{9} \mathrm{H}_{8} \mathrm{~N}_{6} \mathrm{~S} ; \mathrm{C}, 46.6 \% ; \mathrm{H}, 3.4 \%$;
N, 36.1\%; IR: $3350\left(-\mathrm{NH}_{2}\right) ; 1600$ (-C=N-); 690 (C$\mathrm{S}-\mathrm{C}) ; 1 \mathrm{HNMR}\left(\mathrm{CDCl}_{3}\right): 3.80\left(\mathrm{~s}, 2 \mathrm{H}, \mathrm{N}-\mathrm{CH}_{2}\right), 4.40$ (s, 2H, $\left.-\mathrm{NH}_{2}\right)$, and 6.95-7.81 (m, 4H, ArH); MS: $\mathrm{m} / \mathrm{z} 232\left(\mathrm{M}^{+}\right)$.

1-(5-((1H-benzo[d][1,2,3]triazole-1-yl)methyl)-1, 3, 4-thiadiazole-2-yl) -3-ethyl thiourea, 4: Compound 3 (20 m mole) and ethyl isothiocyanate (20 m mole) in dioxane $(5 \mathrm{ml})$ was heated under reflux for $6 \mathrm{~h}$, concentrated and the residue was recrystallised from dioxane to give 4; yield $84 \%$, m.p. $123-124{ }^{\circ} \mathrm{C}$. Elemental analysis: Found $\mathrm{C}$, $45.10 \% ; \mathrm{H}, 4.1 \% ; \mathrm{N}, 30.73 \%$ Calc. for $\mathrm{C}_{12} \mathrm{H}_{13} \mathrm{~N}_{7} \mathrm{~S}_{2}$; C, 45.13\%; H, 4.10\%; N, 30.70\%; IR: 3210, 3300 $(-\mathrm{NH}-) ; 1610 \quad(-\mathrm{C}=\mathrm{N}-) ; 1155 \quad(\mathrm{C}=\mathrm{S}) ; 1$ 1HNMR $\left(\mathrm{CDCl}_{3}\right): 4.90\left(\mathrm{~s}, 2 \mathrm{H}, \mathrm{N}-\mathrm{CH}_{2}\right), 8.4,8.2(2 \mathrm{~s}, 2 \mathrm{H}$, $2 \mathrm{NH}), 7.25-8.0(\mathrm{~m}, 4 \mathrm{H}, \mathrm{ArH}), 4.43$ (q, $\left.2 \mathrm{H},-\mathrm{CH}_{2^{-}}\right)$ and $1.29\left(\mathrm{t}, 3 \mathrm{H},-\mathrm{CH}_{3}\right) ; \mathrm{MS}: \mathrm{m} / \mathrm{z} 319\left(\mathrm{M}^{+}\right)$

3-(-5-((1H-benzo[d][1, 2, 3]triazole-1-yl)methyl)1, 3, 4-thiadiazole-2-yl)-1-ethyl -4-phenyl-1,3dihydro -2H-imidazole-2-thione, 5 (a) / X1: To a stirred solution of compound $4(10 \mathrm{~m}$ mole $)$ and phenacyl bromide, in glacial acetic acid $(50 \mathrm{ml})$ was heated under reflux for $12 \mathrm{~h}$. The obtained solid was recrystallised from acetic acid to give 5 (a); yield $72 \%$, m.p. 130-131 ${ }^{\circ} \mathrm{C}$. Elemental analysis: Found C, 57.21\%; H, 4.0\%; N, 23.33\% Calc. for $\mathrm{C}_{20} \mathrm{H}_{17} \mathrm{~N}_{7} \mathrm{~S}_{2} ; \mathrm{C}, 57.26 \% ; \mathrm{H}, 4.0 \% ; \mathrm{N}$, 23.37\%; IR: 3100 (CH-Ar); 2930 (CH-aliphatic); $1320(\mathrm{~N}=\mathrm{N})$; $1 \mathrm{HNMR}\left(\mathrm{CDCl}_{3}\right): 4.90(\mathrm{~s}, 2 \mathrm{H}, \mathrm{N}-$ $\left.\mathrm{CH}_{2}\right), 6.8(\mathrm{~s}, 1 \mathrm{H},=\mathrm{CH}), 7.36-8.0(\mathrm{~m}, 9 \mathrm{H}, \mathrm{ArH})$, $4.21\left(\mathrm{q}, 2 \mathrm{H},-\mathrm{CH}_{2^{-}}\right)$and $1.26\left(\mathrm{t}, 3 \mathrm{H},-\mathrm{CH}_{3}\right)$; MS: $\mathrm{m} / \mathrm{z} 419\left(\mathrm{M}^{+}\right)$Other compounds 5(b-f) were synthesized similarly using various isothiocyanate in place of ethyl isothiocyanate. Characterization data are present in Table 1 and Table 3.

\section{Determination of Anticonvulsant Activity} Methods: Preparation of DMF (Dimethylformamide) suspension of synthesized compounds: All synthesized compounds were dissolved in DMF and used as a suspension in physiological saline containing 2 drops of tween 80 and produce a final conc. of $1.0 \mathrm{mg} / \mathrm{ml}$. The standard drug used for this study was phenytoin. Drugs were administered intraperitoneally (i.p.) $30 \mathrm{~min}$ before applying electric shock.

Animals: Swiss-albino mice of either sex weighing 25-35 g obtained from our animal house. The 
animals were housed at $24 \pm 2{ }^{\circ} \mathrm{C}$ with $12: 12 \mathrm{~h}$ light and dark cycle with free access to water and food. The animals were acclimatized for a period of 7 days before the study.

The experimental protocol was approved by the Institutional Animal Ethics Committee (IAEC) of Institute of Pharmacy, Bundelkhand University, Jhansi (U.P.) India. The animals were used according to the CPCSEA guidelines for the use and care of experimental animals.

Experimental Design: On the day of the experiment, the animals were divided randomly into control, standard and experimental groups $(\mathrm{n}=$ 6) with each having 6 animals of either sex and were fasted overnight with water ad libitum. Group 1 received the vehicle, normal saline $(10 \mathrm{ml} / \mathrm{kg}$, orally) and served as the control group, group 2 received the standard drug Phenytoin $(25 \mathrm{mg} / \mathrm{kg}$, i.p.) and group 3 to 8 received DMF suspension of synthesized compounds X1 to X6 Table 2. Drugs were administered to the animals $30 \mathrm{~min}$ before applying electric shock.

\section{Evaluation of Anticonvulsant Activity:}

Maximal Electro Shock (MES) Induced

Seizures: MES model was used for the evaluation of the anticonvulsant effect of synthesized derivatives (X1 to X6). Electro Convulsiometer (Model No EC-02) was used for delivering an electric shock $(50 \mathrm{~mA}$ for $0.2 \mathrm{sec})$ with the help of a corneal electrode to induce hind limb tonic extension (HLTE) in mice ${ }^{17-18}$. The total duration of HLTE, onset of convulsions, and incidence of mortality in all groups of animals were recorded. The animals which did not exhibit HLTE were considered protected.

Statistical Analysis: All results were expressed as mean \pm standard error means (SEM) and analyzed by one-way ANOVA. Post-hoc comparisons were performed by applying Dunnet's test. $\mathrm{P}<0.05$ was considered statistically significant.

\section{RESULTS:}

TABLE 1: CHARACTERIZATION DATA OF SYNTHESIZED COMPOUNDS (5A TO 5F)

\begin{tabular}{cccccc}
\hline Compound $(\mathbf{X})$ & $\mathbf{R}$ & $\mathbf{R}$ & Yield (\%) & m.p. ('C) & Mol. Formula* \\
\hline $\mathrm{X} 1:(5 \mathrm{a})$ & $-\mathrm{C}_{2} \mathrm{H}_{5}$ & $-\mathrm{C}_{6} \mathrm{H}_{5}$ & 70 & $130-131$ & $\mathrm{C}_{20} \mathrm{H}_{17} \mathrm{~N}_{7} \mathrm{~S}_{2}$ \\
$\mathrm{X} 2:(5 \mathrm{~b})$ & $-\mathrm{CH}_{2} \mathrm{CH}_{2} \mathrm{CH}_{3}$ & $-\mathrm{C}_{6} \mathrm{H}_{5}$ & 87 & $104-105$ & $\mathrm{C}_{21} \mathrm{H}_{19} \mathrm{~N}_{7} \mathrm{~S}_{2}$ \\
$\mathrm{X} 3:(5 \mathrm{c})$ & $-\mathrm{CH}_{2}\left(\mathrm{CH}_{3}\right)_{2}$ & $-\mathrm{C}_{6} \mathrm{H}_{5}$ & 80 & $152-153$ & $\mathrm{C}_{21} \mathrm{H}_{19} \mathrm{~N}_{7} \mathrm{~S}_{2}$ \\
$\mathrm{X} 4:(5 \mathrm{~d})$ & $-\mathrm{CH}_{2}\left(\mathrm{CH}_{2}\right)_{2} \mathrm{CH}_{3}$ & $-\mathrm{C}_{6} \mathrm{H}_{5}$ & 85 & $166-167$ & $\mathrm{C}_{22} \mathrm{H}_{21} \mathrm{~N}_{7} \mathrm{~S}_{2}$ \\
$\mathrm{X} 5:(5 \mathrm{e})$ & $-\mathrm{C}_{2}\left(\mathrm{CH}_{3}\right)_{3}$ & $-\mathrm{C}_{6} \mathrm{H}_{5}$ & 23 & $148-149$ & $\mathrm{C}_{22} \mathrm{H}_{21} \mathrm{~N}_{7} \mathrm{~S}_{2}$ \\
$\mathrm{X} 6:(5 \mathrm{f})$ & $-\mathrm{C}_{6} \mathrm{H}_{5}$ & $-\mathrm{C}_{6} \mathrm{H}_{5}$ & 65 & $132-133$ & $\mathrm{C}_{24} \mathrm{H}_{17} \mathrm{~N}_{7} \mathrm{~S}_{2}$ \\
\hline
\end{tabular}

TABLE 2: EXPERIMENTAL DESIGN

\begin{tabular}{ccc}
\hline Groups & Treatment & Dose \\
\hline I & Normal Saline & $10 \mathrm{ml} / \mathrm{kg}$, orally \\
II & Phenytoin & $25 \mathrm{mg} / \mathrm{kg}$, intraperitoneally \\
III & Compound $X_{1}$ & $50 \mathrm{mg} / \mathrm{kg}$, orally \\
IV & Compound $X_{2}$ & $50 \mathrm{mg} / \mathrm{kg}$, orally \\
V & Compound $X_{3}$ & $50 \mathrm{mg} / \mathrm{kg}$, orally \\
VI & Compound $X_{4}$ & $50 \mathrm{mg} / \mathrm{kg}$, orally \\
VII & Compound $X_{5}$ & $50 \mathrm{mg} / \mathrm{kg}$, orally \\
\hline
\end{tabular}

TABLE 3: SPECTRAL DATA OF 2-(SUBSTITUTED)-5- [(N-BENZOTRIAZOLOMETHYL)-1, 3, 4-THIADIAZOLYL]IMIDAZOLE-2- THIONE DERIVATIVES

\section{A. INTERPRETATION OF IR SPECTRA:}

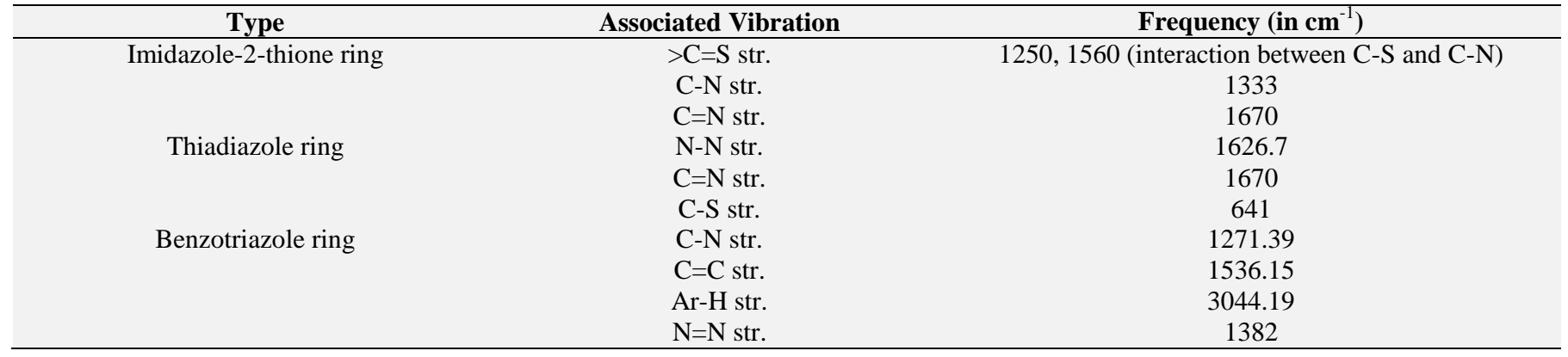




\section{B. INTERPRETATION OF 1H-NMR SPECTRA:}

\begin{tabular}{ccc}
\hline Signal position & Relative no. of protons & Inference \\
\hline $7.68-8.0$ & $9 \mathrm{H}$ & Ar-H \\
4.98 & $2 \mathrm{H}$ & $-\mathrm{CH}_{2}$ link between benzotriazole and thiadiazole \\
6.8 & $1 \mathrm{H}$ & $-\mathrm{CH}$ of imidazole \\
4.2 & $2 \mathrm{H}$ & $>\mathrm{N}^{-} \mathrm{CH}_{2}$ - of imidazole \\
1.26 & $3 \mathrm{H}$ & $>\mathrm{N}-\mathrm{CH}_{2}-\mathrm{CH}_{3}$ of imidazole \\
\hline
\end{tabular}

TABLE 4: MES INDUCED SEIZURES IN MICE

\begin{tabular}{ccccc}
\hline Groups & $\begin{array}{c}\text { Number of animals } \\
\text { convulsed }\end{array}$ & $\begin{array}{c}\text { Number of animals } \\
\text { used }\end{array}$ & $\begin{array}{c}\text { Animals protected } \\
\text { against seizures (\%) }\end{array}$ & $\begin{array}{c}\text { Duration of HLTE } \\
\text { (in seconds) }\end{array}$ \\
\hline Control $(10 \mathrm{ml} / \mathrm{kg}$, orally) & 6 & 6 & 0 & $15.02 \pm 0.10$ \\
Phenytoin $(25 \mathrm{mg} / \mathrm{kg}, \mathrm{i} . \mathrm{p})$. & 0 & 6 & 100 & $4.00 \pm 0.07^{* *}$ \\
$\mathrm{X}_{1}(50 \mathrm{mg} / \mathrm{kg}$, orally) & 5 & 6 & 16 & $12.96 \pm 0.17^{* *}$ \\
$\mathrm{X}_{2}(50 \mathrm{mg} / \mathrm{kg}$, orally) & 3 & 6 & 50 & $7.34 \pm 0.16^{* *}$ \\
$\mathrm{X}_{3}(50 \mathrm{mg} / \mathrm{kg}$, orally) & 3 & 6 & 50 & $7.34 \pm 0.16^{* *}$ \\
$\mathrm{X}_{4}(50 \mathrm{mg} / \mathrm{kg}$, orally) & 5 & 6 & 16 & $12.90 \pm 0.17^{* *}$ \\
$\mathrm{X}_{5}(50 \mathrm{mg} / \mathrm{kg}$, orally) & 5 & 6 & 16 & $11.94 \pm 0.17^{* *}$ \\
$\mathrm{X}_{6}(50 \mathrm{mg} / \mathrm{kg}$, orally) & 1 & 6 & 83 & $5.56 \pm 0.13^{* *}$ \\
\hline
\end{tabular}

Values are expressed as Mean \pm S.E.M., ${ }^{*} \mathrm{p}<0.05,{ }^{* *} \mathrm{p}<0.01$ Compared with control. HLTE: hind limb tonic extension.

MES-Induced Seizures: Treatment with the derivatives of synthesized compounds X2, X3 and $\mathrm{X} 6$ showed significant protection of animals in MES-induced convulsion exhibited protection against HLTE-induced electric shock with maximum protection $(83 \%)$ by X6. The compounds $\mathrm{X} 2$ and $\mathrm{X} 3$ also showed a significant reduction in latency time of convulsion when compared with control, wherein the maximum reduction in tonic seizures duration was exhibited with X6 (83\%). Standard drug phenytoin also exhibited protection (100\%) against HLTE Table 4.

DISCUSSION: The aim of the present study was to investigate the protective effects of synthesized compounds (X1 to X6) on experimental models of convulsions. The MES-induced seizure model is used primarily as an indication for compounds that are effective in grand mal epilepsy ${ }^{19-20}$. The present study revealed that the compounds X2, X3 and X6 attenuated the MES-induced tonic seizures indicating that the compounds possess anticonvulsant effects. In the MES induced convulsions, the synthesized compounds $\mathrm{X} 2, \mathrm{X} 3$ and $\mathrm{X} 6$ significantly reduced the latency and showed good protection. The effect was comparable with the standard anticonvulsant drug, phenytoin in their respective model of convulsion.

It is difficult to elucidate the exact mechanism responsible for the anticonvulsant action of these synthesized compounds. Most of the anticonvulsant drugs like phenytoin inhibit voltage-dependent $\mathrm{Na}^{+}$ channels and prevent tonic extension in MESinduced convulsion ${ }^{21-24}$. Hence, it is possible that synthesized compounds X2, X3 and X6 may have an influence on voltage-gated $\mathrm{Na}^{+}$channels. It was observed that the alkyl group in the synthesized derivatives at $\mathrm{N}-1$ position of imidazolo-thione ring must contain a chain of three carbons (n-propyl or isopropyl) as in $\mathrm{X} 2$ and $\mathrm{X} 3$ respectively, to produce anticonvulsant activity while replacement of open chain with an aromatic substituent, at this place (X6), potentiate anticonvulsant property.

CONCLUSION: The derivatives of benzotriazole (X1 to X6) were synthesized with the objective to develop better anticonvulsant agents with a maximum percentage of yield and optimal anticonvulsant activity. The results of the present study suggest that the synthesized compounds $\mathrm{X} 2$, $\mathrm{X} 3$ and $\mathrm{X} 6$ have produced a significant $(\mathrm{P}<0.01)$ delay in onset of seizures in the MES model on oral administration $(50 \mathrm{mg} / \mathrm{kg}$, orally) which is comparable to Phenytoin ( $25 \mathrm{mg} / \mathrm{kg}$, i.p.) and showed good protection against MES induced seizures $(50 \%, 50 \%$ and $83 \%)$.

Further, investigations with appropriate structural modification of title compound as well as dosedependent study may result in therapeutically useful products. Further studies are required to elucidate the possible mechanism of anxiolytic activity and its usefulness in human beings. 
ACKNOWLEDGEMENT: Authors are very thankful for the head, SAIF, Punjab University, Chandigarh and SAIF, CDRI, Lucknow for providing FT-IR and NMR spectra. Head, Institute of Pharmacy, Bundelkhand University, Jhansi (UP) and Monad University, Hapur, India for providing necessary facilities to carry out this work.

CONFLICTS OF INTEREST: There are no conflicts of interest between the authors or anybody else with respect to material and research presented in this article.

ETHICAL APPROVAL: The Institutional Ethics Committee approved the study. The approval no. is BU/Pharm./IAEC/13/23.

\section{REFERENCES:}

1. Ackerman P and Max S: US Patent No: 5, 322, 853, 1994.

2. Suma BV, Natesh NN, Venkataraman CHS, Jays J and Madhavan V: Synthesis and Antibacterial activity of Some New 1, 2, 3 Benzotriazoles Derivatives Containing Pyrazolidinedione Moieties. Inter J Pharm Sci 2012; 4(1): 169-73.

3. Gaikwad ND, Patil SV and Bobade VD: Synthesis and biological evaluation of some novel thiazole substituted benzotriazole derivatives. Bioorg Med Chem Lett 2012; 22(10): 3449-54.

4. Kopańska K, Najda A, Żebrowska J, Chomicz L and Piekarczyk J: Synthesis and activity of $1 \mathrm{H}$-benzimidazole and 1H-benzotriazole derivatives as inhibitors of Acanthamoeba castellanii. Bioorg Med Chem 2004; 12(10): 2617-24.

5. Purohit $M$ and Srivastava SK: Studies in aryloxylated benzotriazoles. Indian J Pharm Sci 1992; 54(1): 25-27.

6. Jamkhandi CM, Kumbhar PS, Disouza JI and Patil SM: Europ J Pharm Med Res 2015; 2(4): 1004-10.

7. G Caliendo, F Fiorino, E Perissutti, B Severino and D Scolaro: Eur J Pharm Sci 2002; 16: 15-28.

8. Patil GK, Patil HC, Patil IM, Borse SL and Pawar SP: Benzotriazole-the molecule of diverse biological activities. World J of Pharand Pharma Sciences 2015; 4(5): 532-48.

9. Yu KL, Zhang Y, Civiello RL, Kadow KF and Cianci C: Fundamental structure-activity relationships associated with a new structural class of respiratory syncytial virus inhibitor. Bioorg Med Chem Lett 2003; 13(13): 2141-44.
10. Dawood KM, Gawad AH, Rageb EA, Ellithey $M$ and Mohamed HA: Synthesis, anticonvulsant, and antiinflammatory evaluation of some new benzotriazole and benzofuran-based heterocycles. Bioorganic and Medicinal Chemistry 2006; 14(11): 3672-80.

11. Bernatowicz AN, Łebska M, Orzeszko A, Kopańska K and Krzywińska E: Synthesis of new analogs of benzotriazole, benzimidazole and phthalimide-potential inhibitors of human protein kinase CK2. Bioorg Med Chem 2009; 17(4): 1573-78.

12. Nag D: Gender and epilepsy: a Clinician's experience. Neurol Ind 2000; 48: 99-104.

13. Gasior M, Carter RB, Goldberg SR and Witkin JM: Anticonvulsant and behavioural effects of neuroactive steroids alone and in conjunction with diazepam. J Pharmacol Exp Ther 1997; 282: 543-53.

14. Eurniss BS, Hannaford AJ, Smith PWG and Tatchell AR: Vogel's text book of practical organic chemistry, edn $5^{\text {th }}$, Addison Wesley Longman Ltd, Harlow, England 1989.

15. Ullmann F, Gerhartz W, Yamamoto YS, Campbell FT and Pfefferkorn R: Ulmann's Encyclopedia of Industrial Chemistry A2, 411985.

16. Soloman G and Fryhle G: Organic chemistry, edn $7^{\text {th }}$ John Willey and Sons Inc. New Delhi, India 2000.

17. Kulkarni SK: Hand book of experimental pharmacology. Edition $3^{\text {rd }}$, Vallabh Prakashan, New Delhi, India 1999.

18. Swinyard EA, Brown WC and Goodman LS: Comparative assays of antiepileptic drugs in mice and rats. J Pharmacol Exp Ther 1952; 106: 319-30.

19. DeSarro G, Ferreri G, Gareri P, Russo E, DeSarro A, Gitto $\mathrm{R}$ and Chimirri A: Comparatie anti-convulsant activity of some 2, 3-benzodiazepine derivaties in rodents. Pharmacol Biochem Behav 2003; 74: 595-02.

20. Löscher W and Schmidt D: Which animal models should be used in the search for new antiepileptic drugs? A proposal based on experimental and clinical considerations. Epilesy Res 1988; 2: 145-81.

21. Browning R: The electro shock model, neuronal network and antiepileptic drugs. In: Faingold CL, Fromm GH (eds). Drugs for control of epilepsy: actions on neuronal networks in seizure disorders. CRC Press, Boca Raton, FL, 1992.

22. Liow K, Barkley GL, Pollard JR, Harden CL and Bazil CW: Position statement on the coverage of anticonvulsant drugs for the treatment of epilepsy. Neurology 2007; 68: 1249-50.

23. Rho JM and Sankar R: The pharmacologic basis of antiepileptic drug action. Epilepsia 1999; 40: 1471-83.

24. Rogawski MA and Porter RJ: Antiepiletic drugs: pharmacological mechanisms and clinical efficacy with consideration of promising developmental stage compounds. Pharmacol Rev 1990; 42: 223-86.

How to cite this article:

Singh VK, Rishishwar P, Bharadwaj P and Alok S: Synthesis and anticonvulsant activity of some novel benzotriazole derivatives. Int $\mathrm{J}$ Pharm Sci \& Res 2020; 11(1): 352-57. doi: 10.13040/IJPSR.0975-8232.11(1).352-57.

All @ 2013 are reserved by the International Journal of Pharmaceutical Sciences and Research. This Journal licensed under a Creative Commons Attribution-NonCommercial-ShareAlike 3.0 Unported License.

This article can be downloaded to Android OS based mobile. Scan QR Code using Code/Bar Scanner from your mobile. (Scanners are available on Google Playstore) 